\title{
Vermicomposting Methods from Different Wastes: An Environment Friendly, Economically Viable and Socially Acceptable Approach for Crop Nutrition: A Review
}

\author{
Ali Ahmad ${ }^{1, *}$, Zubair Aslam ${ }^{1}$, Korkmaz Bellitürk², Naeem Iqbal ${ }^{3}$, Shoaib Naeem ${ }^{1}$, Muhammad Idrees $^{3}$, \\ Zohaib Kaleem ${ }^{4}$, Muhammad Yasir Nawaz ${ }^{5}$, Muhammad Nawaz ${ }^{6}$, Muhammad Sajjad ${ }^{1}$, Wajeeh Ur \\ Rehman', Hafiz Naveed Ramzan", Muhammad Waqas', Yousuf Akram¹, Muhammad Asif Jamal', \\ Muhammad Usman Ibrahim ${ }^{1}$, Hafiz Amir Tauqeer Baig', Ahmad Kamal ${ }^{1}$ \\ ${ }^{1}$ Department of Agronomy, University of Agriculture Faisalabad, 38000, Pakistan. \\ ${ }^{2}$ Department of Soil Science and Plant Nutrition, Faculty of Agriculture, Tekirdag Namık Kemal University, Suleymanpasa Tekirdag, \\ Turkey. \\ ${ }^{3}$ Plant Physiology Section, Agronomic Research Institute, AARI, Faisalabad, Pakistan. \\ ${ }^{4}$ Department of Botany, University of Agriculture Faisalabad, 38000, Pakistan. \\ ${ }^{5}$ Department of Pathology, Faculty of Veterinary Science, University of Agriculture Faisalabad, 38000, Pakistan. \\ ${ }^{6}$ Vegetable and Oil Seed Section, Agronomic Research Institute, AARI, Faisalabad, Pakistan. \\ ${ }^{7}$ Fiber Crops Section, AARI, Faisalabad, Pakistan.
}

\begin{abstract}
How to cite this paper: Ali Ahmad, Zubair Aslam, Korkmaz Bellitürk, Naeem Iqbal, Shoaib Naeem, Muhammad Idrees, Zohaib Kaleem, Muhammad Yasir Nawaz, Muhammad Nawaz, Muhammad Sajjad, Wajeeh Ur Rehman, Hafiz Naveed Ramzan, Muhammad Waqas, Yousuf Akram, Muhammad Asif Jamal, Muhammad Usman Ibrahim, Hafiz Amir Tauqeer Baig, Ahmad Kamal. (2021) Vermicomposting Methods from Different Wastes: an Environment Friendly, Economically Viable and Socially Acceptable Approach for Crop Nutrition: A Review. International Journal of the Science of Food and Agriculture, 5(1), 58-68.

DOI: 10.26855/ijfsa.2021.03.009
\end{abstract}

Received: December 25, 2020

Accepted: January 26, 2021

Published: February 4, 2021

*Corresponding author: Ali Ahmad, Department of Agronomy, University of Agriculture Faisalabad, 38000, Pakistan.

Email: aliahmadsial2643@gmail.com

\begin{abstract}
The waste management and crop residues are serious problems in the world. Major crops like rice, wheat, sugarcane residues burning causes environmental pollution like smog. The best technique to manage all kind of waste is vermicomposting that is environment friendly, economically viable and socially acceptable approach which convert garbage in to black gold that is called vermi-fertilizer. Compositing process is mainly involved for increased transformation of organic decay within stable organic compound via the interaction of beneficial microorganisms under regulate increased temperature $45^{\circ} \mathrm{C}-60^{\circ} \mathrm{C}$ that permits sanitation of organic decay by eradication harmful microbes. In preparation of vermicompost, organic waste products are being oxidized via the mutual activity of useful microbes and earthworm. Vermi-fertilizer is rich source of all macro and micro nutrients, i.e., Nitrogen $(\mathrm{N})$, Phosphorous $(\mathrm{P})$, Potassium $(\mathrm{K})$, Iron $(\mathrm{Fe})$, Zinc $(\mathrm{Zn})$, Copper $(\mathrm{Cu})$, manganese $(\mathrm{Mg})$, growth promoters and regulators hormones like Auxin, gibberellin, enzymes i.e., protease, lipase, chitinase, beneficial bacterias i.e., Bacillus subtilis. Almost 3,000 species of earthworms are identified for vermicomposting, in which Eisenia fetida, Eisenia Andrei, Eudrilus eugeniae and Perionyn excavates are most suitable for vermicompost preparation.
\end{abstract}

\section{Keywords}

Black-Gold, Garbage, Vermicomposting, Vermi-Fertilizer, Waste Management

\section{Introduction}

In conventional agriculture system use of chemical fertilizers has increased from green revolution to increase the production of crops. There is no doubt chemical fertilizers increased crop productivity in many ways, but their imbal- 
ance and continuous use has also produced harmful effect on soil health due to that reason from past few years yield of crop reduced. The effect of chemical fertilizer has been studied under an experiment which shows continuous use of sole fertilizer produced harmful effect on soil chemical, physical and biological properties, inducing deficiency of micronutrient in soil and nutrient imbalance in soil and plants, environmental hazards and decrease in total factor productivity. Microbial activity and population in soil also badly affected due to irregular fertilizer application. Moreover, excessive fertilizer applications are also contaminating surface and underground water bodies especially by nitrate leaching [1] and causing harmful effects on environment, which also create health problem for human and animals. Therefore, in present context, there is dire need to follow climate resilient integrated crop management modules so that soil health and crop productivity could be sustained for longer time. To reduce the above problem decrease the use of chemical fertilizers could be recycling of organic material. Thus, vermicompost is best option for organic manure management in crop production, soil health improvement, quality and production enhancement and it also play a significant role on microbial activity and soil properties. Vermicomposting is a method of converting agricultural waste into nutrient-rich compost using earthworms. In agriculture, soil earthworms play an important role, decomposing dead organic litter by eating it and releasing it as castings. The earthworms improve the decomposition of dead plant debris and litter and increase soil fertility by releasing nutrients and minerals in the form of nitrate and other types for plant uptake [2]. It contains nutrient in plant available form such as phosphate, soluble potassium, nitrate and exchangeable calcium [3, 4]. The behavioral activity of earthworms feeding, casting, and burrowing modify the physical, chemical and biological properties of organic matter. They also increase the nutrient of soil and improve plant growth. Due to large surface area, vermicompost offers several micro sites for nutrient retention, exchange and microbial activity [5]. Vermicompost is usually rich in microbes and diversity particularly bacteria, fungi and actinomycetes [3,6]. The compost prepared by earthworm contains several types of enzymes, hormones, vitamins, antibiotics and many essential nutrients needed for plant growth and also play important role in improving soil structure and water holding capacity, also improving crop productivity and quality. Vermicompost is associated in induction of high porosity, aeration, drainage, capacity to retain water and microbial activity [7, 8]. Vermicomposting is a method of converting agricultural waste into nutrient-rich compost using earthworms. In agriculture, soil earthworms play an important role, decomposing dead organic litter by eating it and releasing it as castings. The earthworms improve the decomposition of dead plant debris and litter and increase soil fertility by releasing nutrients and minerals in the form of nitrate and other types of plant uptake. As a whole, due to their different production processes, vermicompost might exhibit different physical, chemical and biological features, which influenced plant growth and overall morphology in diverse ways. Thus, applying vermicompost as organic manure to soil organic carbon, improving nutrient contents, enhancing cation exchange ability, microbial activities, microbial biomass carbon and enzymatic activities.

\section{Vermicomposting vs. traditional composting}

Composting is a process in which organic matter decay with the interaction of beneficial microorganisms under regulated increased temperature $45^{\circ} \mathrm{C}-60^{\circ} \mathrm{C}$, that allows sanitation of organic decay by eradication of harmful microbes [9]. It occur in two phases, including thermophilic stage, in which degradation of organic waste occurs more frequently under specific temperature of 45 to 65 degree Celsius and other stage is mesophilic stage, in which temperature $20^{\circ} \mathrm{C}-35^{\circ} \mathrm{C}$ reduce, and the resting not decomposed substance degraded at moderate rate. The period of every decomposing phase majorly depends upon the organic waste's nature, aeration and moisture.

In preparation of vermicompost, organic waste products are being oxidized via the mutual activity of useful microbes and earthworm [10]. Earthworm apparently degrade and intermingle the organic mass by exchange via amendment of its chemical and physical nature and slowly decreasing the ratio of (C: $N$ ), and enhancing the area of surface to microbe for accelerating their activity and farther decomposition of organic matter. In vermicomposting process, there are generally two phases, in initial stage, earthworms apparently get degraded and mix the organic matters by enhancing surface area to earthworm for accelerated decomposition of the organic masses and the secondary phase, ingested wastes consumed by earthworms replace into fresh substances where the microbe regulate decomposition process [11]. Earthworm populations and species and the characteristics of organic matter, humidity, ventilation of the medium have a direct correlation for enhancing decomposition process. Moreover, it was concluded that soil and crop production could be improved by some earthworm epigeic species ingested organic matters [12, 13]. Vermicompost technique spreading very quickly while scientific community is not serious with this method of organic amendment [14].

Earthworms are sexually hermaphrodite and reproduce generally through cross fertilization and copulation which resultantly very of the copulated species yields cocoons consisting fertilized ova of 1-20 in number. They classified according to their feeding and burrowing plans with environmental groups like anecic, epigeic and endogeic [15]. Anecic and Endogeic group are present in beneath soil and obtained food from both inorganic and organic minerals, their excreta also contain organic minerals where as epigeic groups are present on surface and their food is surface litters and they are known surface litter converters. Different species of earth worms feed different material shown in (Table 1, Figure 5). They obtained feeding over course organic matter and utilize undecomposed surface litters. 
Table 1. Details of work rendered on vermicompost

\begin{tabular}{ccc}
\hline Material used & Species used & Reference \\
\hline Sugar cane press mud + Horse manure & $($ Eisenia fetida $)$ & {$[16]$} \\
Coffee pulp & $($ Eisenia fetida $)$ & {$[4]$} \\
Textile mill sludge & $($ Eisenia fetida $)$ & {$[17]$} \\
Guar gum & $($ Eisenia fetida $)$ & {$[18]$} \\
Mango leaves & $($ Eisenia fetida $)$ & {$[19]$} \\
Horse waste & $($ Eisenia fetida $)$ & {$[17]$} \\
Cattle dung & $($ Eisenia fetida $)$ & {$[20,21,22,23]$} \\
Pig waste & $($ Eisenia fetida $)$ & {$[24]$} \\
Poultry droppings & $($ Eisenia fetida $)$ & {$[17]$} \\
Turnkey waste & $($ Eisenia fetida $)$ & {$[21]$} \\
Solid paper mill Sludge & $($ Eisenia andrei $)$ & {$[25]$} \\
Water hyacinth & $($ Eisenia fetida $)$ & {$[26]$} \\
Sheep waste & $($ Eisenia fetida $)$ & {$[21]$} \\
Cow slurry & & {$[27]$} \\
\hline
\end{tabular}

\section{Earthworms and raw material for vermicomposting}

More than 3000 species of earthworm are present in soil but hardly 8-10 species are suitable for vermicompost preparation [29]. The best types of earthworms for vermiculture and vermicomposting are epigaeic species such as Eisenia fetida and Eudrilus eugeniae [22, 30]. These worm species prefer to live on upper surface of soil and eat organic material like vegetable waste, compost, organic bedding and produce rich material as compared to those who feed on plain soil. These species eat much as half of its weight on daily basis as compared to other species they produced high quality organic compost by breaking and decaying of natural remains. Further, above species of earthworms are resistant to moisture and temperature fluctuations. These species remain active whole the year and decompose organic matter very rapidly and prepare vermicompost in short duration. Other species of red worms like Lumbricus rubellus, Perionyx sansibaricus, Perionyx excavatus, Eisenia andreii, etc., could also be successfully used in vermicompost production [30]. Any easily decomposed material used for vermicomposting such as cow dung, weeds, fruits and vegetables leaves, animal roughing, crop residues (Figure 1), as well a municipal wastes of organic origin also utilized in vermicomposting Aslam et al. [31], Belliturk et al. [32]. Organic waste ingested by earthworm is physically broken down into the gizzard and then exposed to different enzymes such as chitinase, cellulose, lipase, amylase protease etc., secreted into lumen by the gut wall and associated microbes. These enzymes break complex biomolecules into simple forms. Secretion of mucus from gut wall gives stability of vermicompost. Only 5\%-10\% of the ingested material is absorbed by earthworms for their growth and remaining is excreted as casting.

\section{Selection of site for vermicompost preparation}

Selection of proper place is necessary for any living organism to perform better functions. Generally, earthworms like to live in shady and moist places and such conditions are suitable for their faster multiplication. Worms remain alive under low and water saturated environment as compared to high temperature and dry condition [33]. Earthworm need proper moisture (Figure 6), because it cannot live in standing water, so, ensure proper drainage across vermicompost unit. A temperature range between $20^{\circ} \mathrm{C}-30^{\circ} \mathrm{C}$ is optimum for faster multiplication and growth of the earthworms. Hence, excellent compost quality can be produced under the right earthworm species in a short time under ambient temperature conditions. Following points should be kept in mind before making a vermicompost unit: Select a shady and moist spot preferably under the tree or below the ventilated shed. Ensure proper drainage across the vermicompost bed or unit and source of water should be closure to the unit. It should be far away from biogas plant, otherwise earthworm utilize the carbon of biogas as their food and slow down the process of decomposition of material [34, 32].

\section{Steps involved in vermicompost production}

Composting is an essential step in the reduction and preparation of a naturally beneficial soil additive. Vermicompost is an effective and alternative composting method that allows for a minimum composting space. It is very interesting 
topic for every in the world. The production of quality vermicompost from the raw waste requires much knowledge of the process. The various steps involved in vermicompost production are given: Firstly select a proper site then after selection of site for vermicompost preparation, smoothen the surface. Now, make a bed of approximately $10 \times 3 \times 3$ feet $(\mathrm{L} \times \mathrm{B} \times \mathrm{H})$ with bricks. However, size of the bed could be decreased or increased as per the quantity of material available and need. Moisten the surface of the bed by sprinkling the water (Figure 6). Now, at the base of the bed, spread 2-3 inch thick layer of dry leaves or paddy straw, etc (Figure 1). Again sprinkle some amount of water over layer of dry material. Spread about 1-1.5 feet thick layer of farm yard manure or cow dung uniformly over leaves or straw layer and sprinkler water to make it sufficient moist. The cow dung should not too fresh (Figure 3). It should be 10-15 days old at least, since fresh cow dung is heating and the earthworms can be destroyed. Similarly, it should be 10-15 days old at least, since fresh cow dung is exhausted heat and the earthworms can be destroyed. Similarly, cow dung should not be too old as it was decomposed, and earthworms will not get any food from it. Now, add the kitchen waste such as leaves of vegetables, fruits rind and or grasses, roughages of animals, etc. by chopping them into small pieces. Again, spread about 1-1.5 feet layer of cow dung uniformly and sprinkler sufficient quantity of water. Spread about one kg vermiculture (contain about 800-1,000 earthworms) over the layer of cow dung. Again spread 2-3 inch layer of green leaves, etc. uniformly over the layer of FYM and sprinkle water. Now, cover the vermicompost bed with the help of jute/gunny bags (Figure 4). For maintaining optimum moisture and temperature conditions in the vermicompost bed, regularly sprinkler the water over the gunny bags. There should be about $35 \%-40 \%$ moisture and $15^{\circ} \mathrm{C}-30^{\circ} \mathrm{C}$ temperature in the bed stated by Aslam et al. [35]. Hence, regularly sprinkle water to maintain optimum conditions for earthworm growth and functioning. If, the vermicompost unit is established in the open area then provide a shed/roof over the unit, so that shady conditions could be maintained for the unit and earthworms may be avoided from the direct contact of sun rays and rains. By following above steps, vermicompost is ready in about 8-10 weeks' time. The vermicompost appear dark brown in colour on maturity and is very porous, granulated and free of any foul smell observed by Sami et al. [36].

\section{Harvesting and storage of vermicompost}

When vermicompost (Figure 7) is prepared then stop sprinkling and watering about one week ago and make heap of the compost for better earthworm performance. Now, earthworm starts moving downward and gathered at the bottom of the heap. Further process remove material from heap and kept in shadow for sieving and packing. Sunlight should not directly expose heaped vermicompost, moisture percentage of compost kept minimum $40 \%$, light cause reduction in moisture and ultimately nutrient reduced from compost. Sieving of vermicompost helps to transfer of earthworm to next new bed because lower portion of vermicompost contain maximum amount of earthworms which help in preparation of vermicompost again. It can be used for vegetables, fruits and crops. Vermicompost can be stored for at least one year without any loss of its quality, if the optimum moisture level (40\%) in the vermicompost is maintained Ahmad et al. [37, 32].

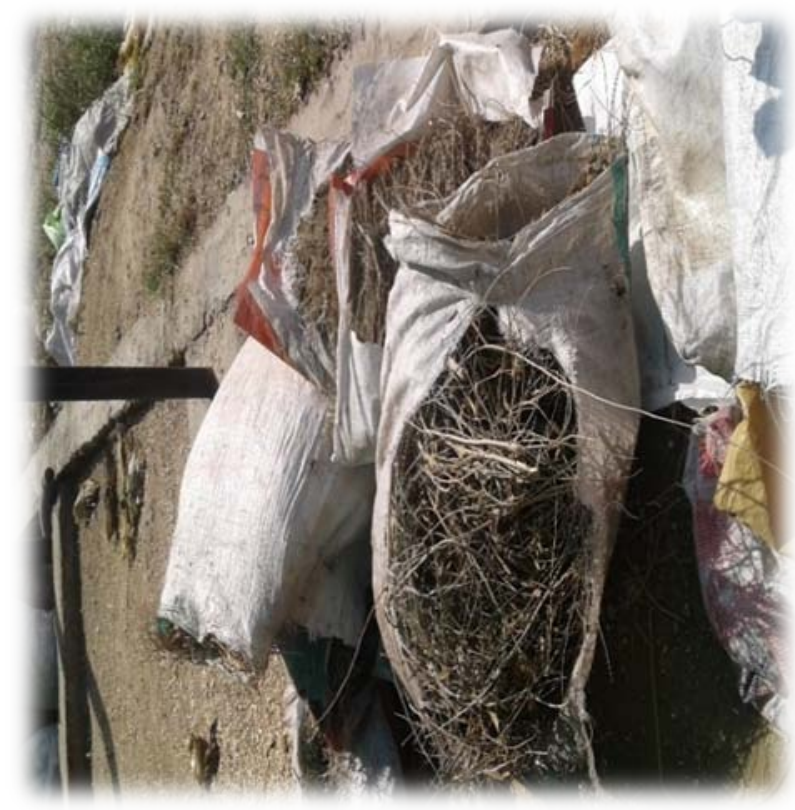

Figure 1. Collection of material.

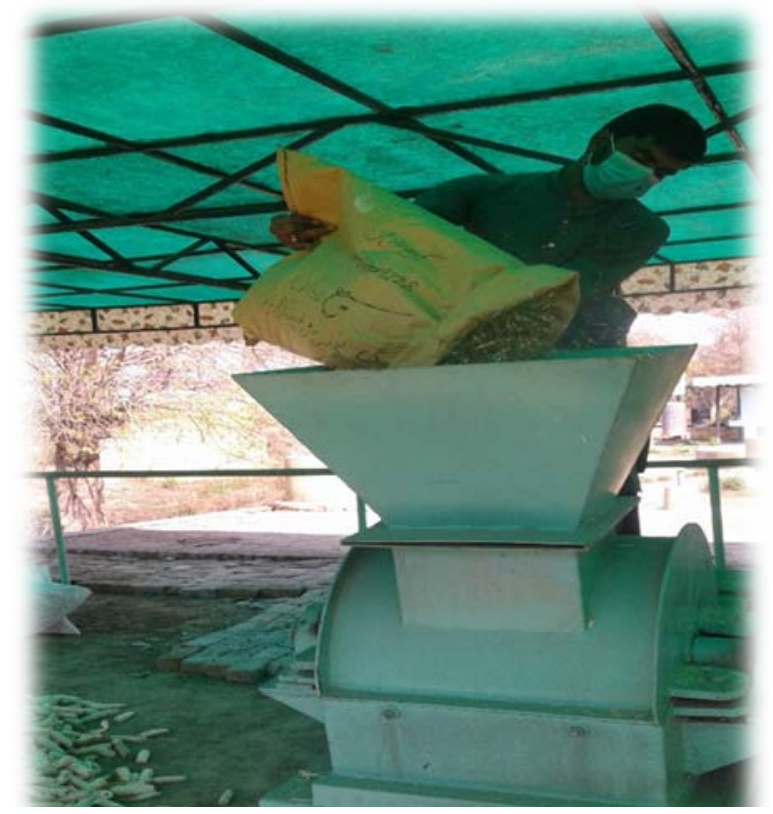

Figure 2. Crushing the material for earth worms. 


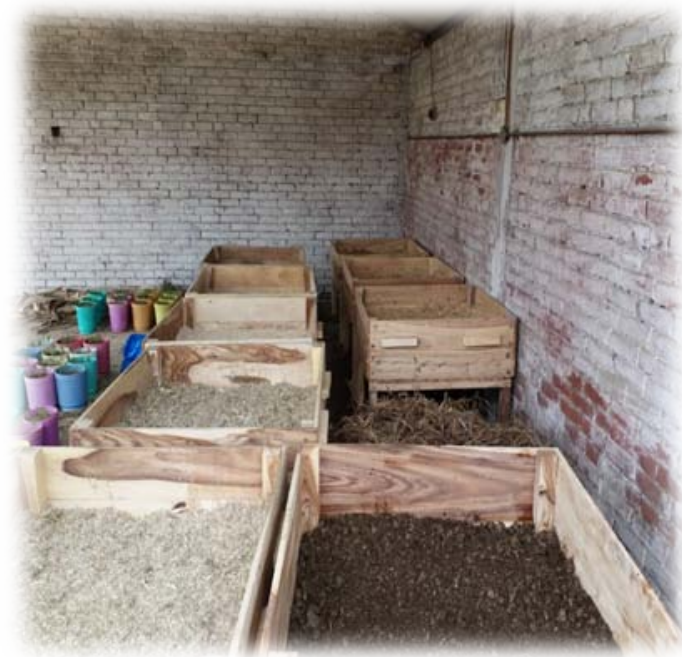

Figure 3. Pre-composting the material.

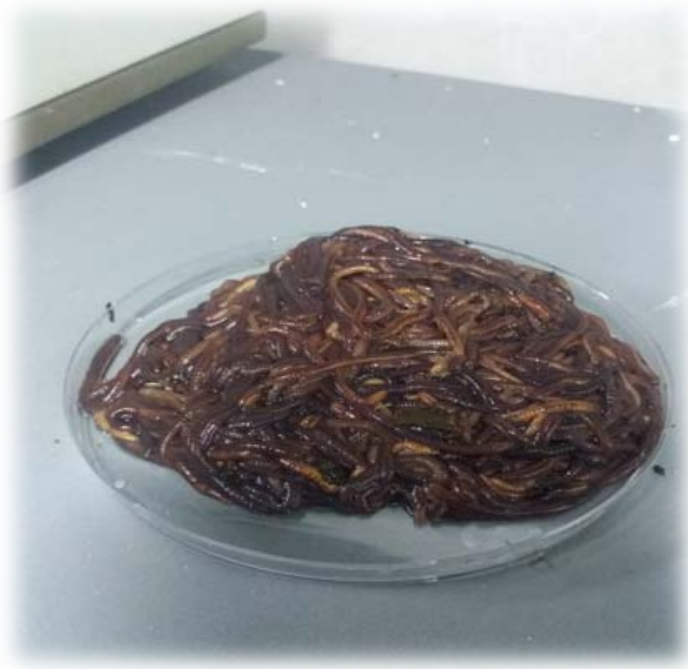

Figure 5. Eisenia fetida.

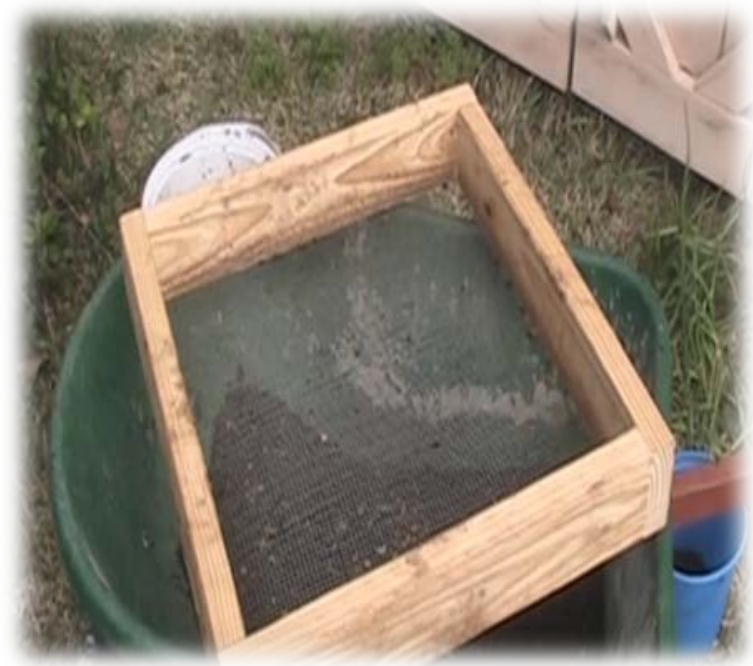

Figure 7. Sieving of vermicompost.

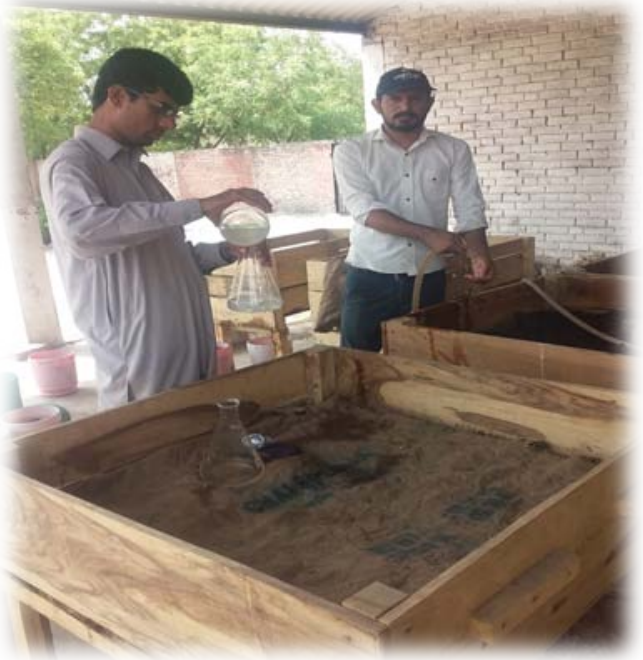

Figure 4. Covered with Jute bags.

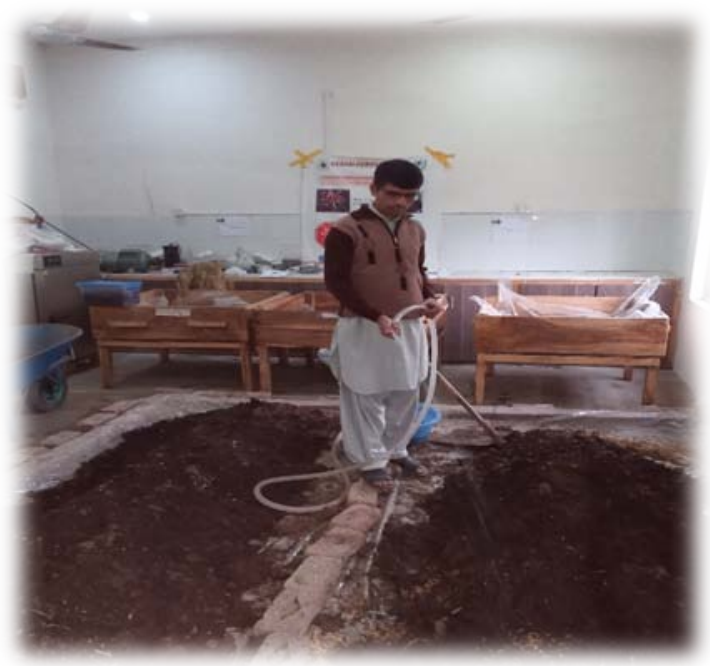

Figure 6. Watering.

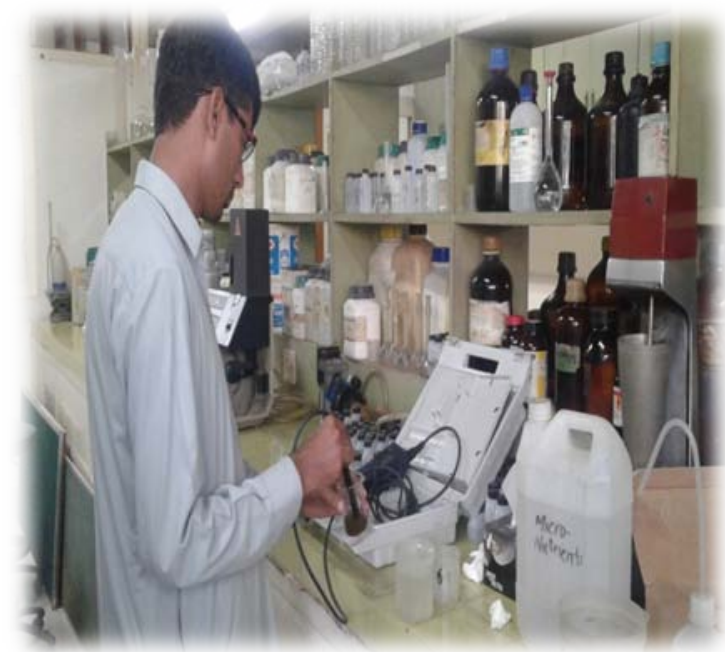

Figure 8. Vermicompost and raw material analysis. 


\section{Application of vermicompost in soil}

In horticultural and field crops application of vermicompost is done for better production because it contains all macro and micro nutrients which are available and greater than raw material used for its production (Table 2, Figure 8). It shows good impact on crop production and also on soil health. Vermicompost application is very simple than other fertilizers applications. Apply it as a thin layer to soil mixing with the soil and around the plants. It commonly applied at the time of last ploughing. Its rate of application depends upon nutritive requirement, quality and crop to which it used. However, different researchers have got best results at different levels of vermicompost in their respective experimentations [38] reported that by the application of vermicompost fertilizer @10 t ha ${ }^{-1}, 50 \%$ tomato yield increased. Similarly, [39] investigated that by applying vermicompost@ $5 \mathrm{t} \mathrm{ha}^{-1}$ tomato yield also increased. Another experiment also gives same results in which rice crop yield increase by applying compost @2.5 t ha ${ }^{-1}$ [40].

\section{Cumulative supplementation of vermicompost, simple compost and chemical fertilizer}

Chemical fertilizer application increases with the improvement and perfection of market economy, which decreases soil fertility and nutrient quality of crops. The increase of chemical fertilizer causing decrease in organic matter contents, which is the primary attributes of the sustainable cultivating frameworks [41]. The application of inorganic fertilizer was found to be suitable for increased in crop production from couple of years, however longer use of inorganic fertilizer degraded the soil fertility and organic matter [42]. Vermicompost, simple compost and chemical fertilizer combined application help in keeping yield and nutrient stability and reduced lack of nutrients, improving the efficacy of associated supplements and ensuring desirable soil physical conditions [43]. Vermicomposts are natural materials which are separated by collaborations between minute microorganisms and earthworms to produce fully balanced natural soil modifications with low C: N proportions (Table 2, Figure 8) [44]. Earthworms improve crop production by raising fertility levels through the excretion of beneficial soil species and the secretion of polysaccharides, proteins and various nitrogen compounds into the dirt [45, 46]. Vermicompost improve the growth and yield of crop plants because it contains humic acid and plant growth hormones [47]. Singh and Wasnik (2013) [48] determined the combined effect of vermicompost and inorganic fertilizer on rosemary (Rosmarinus officinalis L) and found that the use of vermicompost $\left(8 \mathrm{t} \mathrm{ha}^{-1}\right)$ together with N-P-K fertilizer at concentration of (150-25-25 kg ha-1) provided optimal rosemary herbage and oil yield compared to control Adding VC and CF to the crop field may be a very good choice provided the availability of nutrients to sustain soil fertility and productivity [37].

\section{Vermicompost benefits}

Vermicompost is a good quality manure containing a variety of essential nutrients required by crops such as (nitrogen, phosphorus, potassium, calcium, magnesium and micronutrients, i.e. iron, zinc, copper and manganese) in adequate quantities to increase the quality and quantity of crops (Table 2, Figure 8). It improves biological, chemical and physical characteristics of soil. It also improves the soil structure due to that soil permeability and porosity increased. Vermicompost contain excessive amount of antibiotics, vitamins, hormones, enzymes and amino acids that are helpful in growth and development of plants. It provides resistance and nutrient to plants. It also decreases the cost of production and overall cultivation by reducing application of chemical fertilizer. Many harmful weeds like Lantana, Ageratum, Parthenium, and Eupatorium could be used in vermicompost preparation [34].

\section{Effects of vermicompost on crop growth and productivity}

In sustainable agriculture, vermicompost is a potential input which create beneficial effects on soil. It contains high level of humic acid and hormones that create a useful effect on plant health [49, 7]. Vermicompost also has a beneficial impact on vegetative development and stimulating the development of shoot and root [50]. Its application increase morphology of crop plants such as leaf areas [51] and stimulated flowering, increase in the number and biomass of flowers [52, 47] and overall increase in fruit yield [53, 54, 55, 56].

Integration of vermicompost enhances seed germination, seedling growth and increase plant production. It also increases germination percentage and yield of mungbean as compared to control [39]. Similarly, [57] investigated that germination increased with the application of vermicompost than other amendments. Application of vermicompost $10 \mathrm{t}$ $\mathrm{ha}^{-1}$ together with recommended chemical nutrient doses gave maximum pea yield compared with sole use of chemical nutrients [38]. Same results have also been reported [39] while working on tomato. Other scientists also reported that vermicompost contain less heavy metals (Table 3, Figure 8), some growth promoting hormones which are released from earthworms [58, 6, 59]. Addition of hormones in vermicompost shows better result in growth and development of plants and makes the soil rich in nutrients. It increase root length, biomass, plant growth and also overall plant physiology [60]. Positive results of vermicompost addition to soil in tomato crop have also been registered by [61]. Vegetative growth of paddy like shoot weight, root weight, root and shoot length influenced significantly by the addition of vermicompost in 
comparison with sole application of chemical fertilizers [62].

Angadi and Radder [40] reported that rice grain and straw yield increase with the application of vermicompost and save chemical fertilizer NPK up to 50 percent in upland rice. Earthworm produced is better source for productivity enhancement and also indicated the possibility of substituting $50 \mathrm{~kg} \mathrm{~N} \mathrm{ha}^{-1}$ from the recommended dose of $\mathrm{N}$ [63]. Thus, vermicompost usage reduced dependence on costly fertilizer input and enhanced net returns from rice produce [64]. Several studies have witnessed increased biomass and grain yield in different crops following judicious application of vermicompost and chemical fertilizers [65, 66]. Positive changes in the quality of wheat flour because of increased gluten content were reported by [67] in vermicompost imbedded treatments. Beside above presented results, there are several examples in the literature that documented enhanced growth of a wide range of plant species following vermicompost incorporation as it is an instant source of nutrients supply [50,68].

\section{Analysis of vermicompost and raw material}

The pH EC (dS/m), OM (\%), C/N, N (\%), $\mathrm{P}_{2} \mathrm{O}_{5}(\%), \mathrm{K}_{2} \mathrm{O}(\%)$, Ca (\%), Mg (\%), Fe (\%), S (\%), and heavy metals Cd (mg/kg), $\mathrm{Ni}(\mathrm{mg} / \mathrm{kg}), \mathrm{Pb}(\mathrm{mg} / \mathrm{kg}), \mathrm{Hg}(\mathrm{mg} / \mathrm{kg}), \mathrm{Cr}(\mathrm{mg} / \mathrm{kg})$, Sn (mg/kg), of vermicompost and raw material were measured which are shown below in (Table 2 and Table 3).

Table 2. Chemical analysis of raw material and vermicompost

\begin{tabular}{cccccccccccc}
\hline Treatments & $\mathbf{p H}$ & $\mathbf{E C ~ ( d S / m )}$ & $\mathbf{O M}(\%)$ & $\mathbf{C} / \mathbf{N}$ & $\mathbf{N}(\%)$ & $\mathbf{P}_{\mathbf{2}} \mathbf{O}_{\mathbf{5}}(\mathbf{\%})$ & $\mathbf{K}_{\mathbf{2}} \mathbf{O}(\%)$ & $\mathbf{C a}(\%)$ & $\mathbf{M g}(\%)$ & $\mathbf{F e}(\%)$ & $\mathbf{S}(\%)$ \\
\hline Raw material & 7.70 & 4.00 & 75.00 & 18.00 & 0.50 & 0.30 & 0.30 & 2 & 0.20 & 0.20 & 0.10 \\
Vermicompost & 6.50 & 3.00 & 48.00 & 12.00 & 1.40 & 1.0 & 1.00 & 4 & 0.60 & 0.55 & 0.45 \\
\hline
\end{tabular}

Table 3. Chemical analysis for heavy metals of raw material and vermicompost

\begin{tabular}{ccccccc}
\hline Treatments & $\mathbf{C d}(\mathbf{m g} / \mathbf{k g})$ & $\mathbf{N i}(\mathbf{m g} / \mathbf{k g})$ & $\mathbf{P b} \mathbf{( m g} / \mathbf{k g})$ & $\mathbf{H g} \mathbf{( m g} / \mathbf{k g})$ & $\mathbf{C r} \mathbf{( m g} / \mathbf{k g})$ & $\mathbf{S n} \mathbf{( m g} / \mathbf{k g})$ \\
\hline Raw material & 0.95 & 12.20 & 40.46 & 3.22 & 13.00 & 0.25 \\
Vermicompost & 0.40 & 6.30 & 25.30 & 1.02 & 6.15 & 0.05 \\
\hline
\end{tabular}

Aslam and Ahmad. [69], Belliturk et al. [32].

\section{Effects of vermicompost on soil properties}

Earthworm presence in soil makes compact soil porous and improves its water penetration. The behavioral activity of earthworms that eat, burrow and caste, changes the physical, chemical and biological properties of organic matter and soil. As discussed earlier, vermicompost nutrient profile is typically higher than conventional compost. In fact, vermicompost can physically, chemically and biologically improve the soil fertility [70]. Physically, soils supplemented with vermicompost have improved aeration, porosity, lower bulk density and greater potential for water retention. Soil chemical properties have greatly improved, such as electrical conductivity, $\mathrm{pH}$, nutrient and organic matter status (Table 2, Figure 8), leading to improved plant growth and yield due to vermicompost application [35]. Moreover, earthworms secrete several hormones, enzymes and vitamins during casting that promote the activity of other beneficial microbes in the soil, thereby improving soil health. Earthworms' casting contains a high percentage of humus. Humus helps in aggregation of soil particles resulting into better porosity, which in turn improve aeration and water holding capacity of the soils. In addition, humic acid in humus provides binding sites for a variety of plant nutrients, i.e., potassium, iron, calcium, sulphur and phosphorus. These nutrients are stored in humic acid in the form of readily available nutrients and released when needed by plants [71].

Earthworm casts ingested soil might create even more favourable environment to plant growth because of higher moisture content and nutrient availability in fresh casts [72]. Jeyabal and Kuppuswamy [73] have reported increased growth of rice stalks and improvement in soil fertility status following vermicompost application. Earthworm casts are commonly considered to be responsible for better soil structure and enhance soil physical properties, i.e., water retention, resistance to erosion and infiltration [74]. Thus, soils amended with vermicompost have ability to improve soil structure and retain higher moisture content. As discussed earlier, earthworm casts are chemically and biologically rich, hence, soils imbedded with vermicompost have a higher rate of plant growth hormones and humic acid, less root pathogens or soil borne diseases, higher microbial activity and population and exhibit higher cation exchange capacity [47, 75, 76, 77] and overall improvement in plant growth and yield [31, 32]. Lee [78] stated that microorganisms in the worm casts could fix atmospheric $\mathrm{N}$ in amounts that are important for the metabolism of earthworms and as a source of nitrogen for plant growth. The findings of [79] supported above results as they have also been reported five folds' higher infiltration rate in soil following fertilization of vermicompost. 


\section{Effects of vermicompost on soil organic matter}

Vermicompost added soil contains maximum content of organic carbon and nutrient availability as compared to their surrounding soils [80]. The studies undertaken by [81] concluded that vermicompost addition in soil increase organic carbon status, decreased bulk density, enhanced soil porosity and water holding capacities, increased dehydrogenase activity and soil microbes. Organic matter content in worm casts has been reported to be around four times higher than in surface soil, with average values of 48.2 and $11.9 \mathrm{~g} \mathrm{~kg}^{-1}$ soil, respectively [82]. In addition, the contribution of earthworms to $\mathrm{N}$ turnover in cultivated soils ranged from 3 to $60 \mathrm{~kg} \mathrm{ha}^{-1}$ year $^{-1}$ [83], increasing the supply of $\mathrm{N}$ to plants (Table 2, Figure 8) [84, 85].

\section{Precautions during vermicompost production}

Select a shady spot for vermicompost making or providing a shed/roof over the device so that the earthworm can be stopped by direct contact with sunlight and rain. Maintain optimum moisture (Figure 6), and temperature conditions in the vermicompost bed/unit by sprinkling water regularly over the gunny bags. Avoid spraying of any kind of insecticides and fungicides over the vermicompost bed. The height of vermicompost bedding material should not exceed 3-3.5 feet as it may increase the temperature inside the bed and also create aeration problem inside and led to death of earthworm. To escape the earthworm from hen, birds, etc. cover the vermicompost bed with sieve [34, 32].

\section{Conclusion}

Overall, the nutrient profile of vermicompost is typically higher than conventional compost. Vermicompost application in soil not only improves structure and aggregation but also enhance the amount of organic matter, nutrient status, potential for cation exchange, microbial activities, and carbon microbial biomass and enzyme activities. Thereby, help in promoting plant growth and sustain soil health. Hence, this input is proven as boon to the farmers. To take full advantage of vermicompost, plough it well in the soil at the time of sowing. The expenditure on costly chemical fertilizer input may be reduced to some extent by applying vermicompost in crops.

\section{Acknowledgement}

The authors gratefully acknowledge HEC for providing financial support to carry out this research work under HEC projects ["NRPU-HEC project no. 7527/Punjab/NRPU/R\&D/HEC/2017_ Vermicomposting: A resourceful organic fertilizer to improve agriculture production and soil health and Second project "Vermicomposting: An Agricultural Waste Management Technology", Pak-Turk Researchers Mobility Grant Program Phase- II, vide letter No. (PhII-MG-9)/PAKTURK/R\&D/HEC/2018”].

\section{References}

[1] Pimentel, D. (1996). Green Revolution and chemical hazards. Science Total Environment, 188, 86-98.

[2] Curry, J. P. (1987). The invertebrate fauna of grassland and its influence on productivity. The composition of the fauna. Grass Forage Science, 42, 103-120.

[3] Edwards, C. A. (1998). The use of earthworm in the breakdown and management of organic waste. Earthworm in Ecology. ACA Press LLC, Boca Raton, FL, 327-354.

[4] Orozco, F. H., Cegarra, J., Trujillo, L. M., \& Roig. A. (1996). Vermicomposting of coffee pulp using the earthworm Eisenia fetida: effects on C and N contents and the availability of nutrients. Biology and Fertility of Soils, 22, 162-166.

[5] Shi-wei, Z., \& Fu-Zhen, H. (1991). The nitrogen uptake efficiency from 15N labeled chemical fertilizer in the presence of earthworm manure (cast). In: Advances in Management and Conservation of Soil Fauna (Veeresh G.K. et al., Eds.) Oxford and IBH publishing Company, Bombay, 539-542.

[6] Tomati, U., Grappelli, A., \& Galli, E. (1987). The presence of growth regulators in earthworm worked wastes. In: Proceeding of International Symposium on 'Earthworms' (Bonvicini-Paglioi, A.M., Omodeo, P., Eds.), Bologna-Carpi, March 31-April 4, 1985. pp. 423-436.

[7] Edwards, C., \& Burrows, I. (1988). The potential of earthworm compost as plant growth media, 211-219. In: C. Edwards and E. Neuhauser (eds.). Earthworms in waste and environmental management. Academic, The Hague, The Netherlands.

[8] Atiyeh, R. M., Subler, S., Edwards, C.A., \& Metzger, J. (1999). Growth of tomato plants in horticultural potting media amended with vermicompost. Pedobiologia, 43, 724-728.

[9] Zucconi, F., \& Bertoldi, M. D. (1987). Composting specifications for production and characterization of compost from MSW. In: De Bertoldi, M. P. Ferranti, P. L. Hermite, and F. Zucconi, (eds.), Compost, Production Quality and Use, Elsevier Applied Science, London. 30-50.

[10] Dominguez, J., Briones, M. J. L., \& Mato, S. (1997). Effect of diet on growth and reproduction of Eisenia Andrei (Oligochaeta 
Lumbricidae). Pedobiologia, 41, 566-576.

[11] Lores, M., Brandon, M. G., Diaz, D. P., \& Domiguez, J. (2006). Using FAME profiles for characterization of animal wastes and vermicomposts. Soil Biology and Biochemistry, 38, 2993-2996.

[12] Oliver, G. S. (1937). Our Friend the Earthworm. Gardener's Book Club, Volume (8) California.

[13] Barrett, T. J. (1942). Harnessing the Earthworms. Faber and Faber, London.

[14] Bouche, M. B. (1987). Strategies lumbriciennes, In: U. Lohm and T. Persson, (eds.). Soil Organisms as components of Ecosystems, Biology Bulletin, 25, 122-123.

[15] Bouche, M. B. (1977). Strategies lumbriciennes, In: U. Lohm and T. Persson, (eds.). Soil Organisms as components of Ecosystems. Biology Bulletin, 25, 122-123.

[16] Sangwan, P., \& Kaushik, C. P. (2007). Nutrient recovery and management of industrial wastes by employing earthworms: a case study of sugar mill sludge. Science of the Total Environment, 99, 8689-8704.

[17] Garg, V. K., \& Kaushik, P. (2005). Vermistabilization of textile mill sludge spiked with poultry droppings by an epigeic earthworm Eisenia foetida. Bioresource Technology, 96, 1063-1071.

[18] Suthar, S. (2007). Vermicomposting potential of Perionyx sansibaricus (Perrier) in different waste materials. Bioresource Technology, 98, 1231-1237.

[19] Talashilkar, S. C., Bhangarath, P. P., \& Mehta, V. B. (1999). Changes in chemical properties during composting of organic residues as influenced by earthworm activity, Journal of the Indian Society of Soil Science, 47, 50-53.

[20] Edwards, C. A., Burrows I., Fletcher, K. E., \& Jones, B. A. (1985). The use of earthworms for composting farm wastes. In: Gasser, J. K. R. (Ed.), Composting of Agriculture and Other Wastes. Elsevier, Amsterdam, 229-242.

[21] Edwards, C. A. (1988). Breakdown of animal, vegetable, and industrial organic wastes by earthworms, In: C.A. Edwards, and E.F. Newhauser (eds.), Earthworms Waste and Environmental Management, SPB Publishing, The Hague, the Netherlands., 21-23.

[22] Bansal, S., \& Kapoor, K. K. (2000). Vermicomposting of crop residues and cattle dung with Eisenia foetida. Bioresource Technology, 73, 95-98.

[23] Kaushik, P., \& Garg, V. K. (2003). Vermicomposting of mixed solid textile mill sludge and cow dung with epigeic earthworm Eisenia fetida. Bioresource Technology, 90, 311-316.

[24] Chan, P. L. S., \& Griffiths, D. A. (1988). The vermicomposting of pretreated pig manure. Biological Wastes, 24, 57-69.

[25] Butt, K. R. (1993). Utilization of solid paper mill sludge and spent brewery yeast as a feed for soil dwelling earthworms. Bioresource Technology, 44, 105-107.

[26] Gupta R., Mutiyar, P. K., Rawat, N. K., Saini, M. S., \& Garg, V. K. (2007). Development of a water hyacinth based vermireactor using an epigeic earthworm Eisenia foetida. Bioresource Technology, 98, 2605-2610.

[27] Hand, P., Hayes, W. A., Frankland, J. C., \& Satchell, J. E. (1988). The vermicomposting of cow slurry. Pedobiologia, 31, 199-209.

[28] Dominguez, J., \& Edwards, C. A. (2011). Relationship between Composting and vermi composting In: C. A. Edwards., N. Q. Arancon, and R. Sherman (eds.), Vermiculture Technology; Earthworm, Organic Wastes, and Environmental Management. CRC Press Taylor and Francis Group, London. 11.

[29] Cook, S. M. F., \& Linden, D. R. (1996). Effect of food type and placement on earthworm (Aporrectodea tuberculata) burrowing and soil turnover. Biology and Fertility of Soils, 21(3), 201-206.

[30] Dominguez, J., \& Edwards, C. A. (2004). Vermicomposting organic wastes: A review. In: Soil Zoology for Sustainable Development in the 21st Century (Shakir, S. H., Mikhail, W. Z. A., Eds).

[31] Aslam, Z., Ahmad, A., Bellitürk, K., Iqbal, N., Idrees, M., Rehman, W. U., Akbar, G., Tariq, M., Raza, M., Riasat, S., \& Rehman, S. U. (2020). Effects of vermicompost, vermi-tea and chemical fertilizer on morpho-physiological characteristics of tomato (Solanum lycopersicum) in Suleymanpasa District, Tekirdag of Turkey. Pure and Applied Biology, 9(3), $1920-1931$.

[32] Bellitürk, K., Aslam, Z., Ahmad, A., \& Rehman, S. U. (2020). Alteration of physical and chemical properties of livestock manures by Eisenia fetida (Savigny, 1926) and developing valuable organic fertilizer. Journal of Innovative Sciences, 6(1), 47-53.

[33] Rostami, R., Nabaei, A., \& Eslami, A. (2009). Survey of optimal temperature and moisture for worm's growth and operating vermicompost production of food wastes. Journal of Environmental Health, 1(2), 105-112.

[34] Kumar, A., Prakash, C. H. B., Brar, N. S., \& Kumar, B. (2018). Potential of vermicompost for sustainable crop production and soil health improvement in different cropping systems. International Journal of Current Microbiology and Applied Sciences, 7(10), 1042-1055.

[35] Aslam, Z., Ahmad, A., Idrees, M., Iqbal, N., Akbar, G., Ali, U., Ibrahim, M. U., Bellitürk, K., Naeem, S., Nawaz, M., Nadeem, M., Waqas, M., Rehman, W. U., Sajjad, M., Samiullah., \& Akram, Y. (2020). Comparative analysis of nutritional sources on the morpho-physiological characteristics of mung bean (Vigna radiata). International Journal of Agriculture and Food Science, 4(3), 314-322. 
[36] Sami, U. R., Aslam, Z., Bellitürk, K., Ahmad, A., Nadeem, M., \& Waqas, M. (2020). Vermicomposting in Pakistan: Current Scenario and Future Prospectives. Modern Concepts and Developments in Agronomy, 6(1), 617-619.

[37] Ahmad, A., Aslam, Z., Iqbal, N., Idrees, M., Bellitürk, K., Rehman, S. U., Ameer, H., Ibrahim, M. U., Samiullah, \& Rehan, M. (2019). Effect of exogenous application of osmolytes on growth and yield of wheat under drought conditions. Journal of Environmental and Agricultural Sciences, 21, 6-13.

[38] Reddy, R., Reddy, M., Reddy, Y. T. N., Reddy, N.S., Anjanappa, N., \& Reddy, R. (1998). Effect of organic and inorganic sources of NPK on growth and yield of pea (Pisum sativum L.). Legume Research, 21(1), 57-60.

[39] Nagavallemma, K., Wani, S., Stephane, L., Padmaja, V., Vineela, C., Babu, R. M., \& Sahrawat, K. (2004). Vermicomposting: recycling wastes into valuable organic fertilizer. Journal of SAT Agricultural Research, 2, 1-16.

[40] Angadi, V. V., \& Radder, G. D. (1996). In: Organic Farming and Sustainable Agriculture. National Seminar, G.B.P.U.A.T, Pantnagar. 34.

[41] Liu, M., Hu, F., Chen, X., Huang, Q., Jiao, J., Zhang, B., \& Li, H. (2009). Organic amendments with reduced chemical fertilizer promotes soil microbial development and nutrient availability in a subtropical paddy field: the influence of quantity, type and application time of organic amendments. Applied Soil Ecology, 42, 166-175.

[42] Satyanarayana, V., Murthy, V. R. K., Vara Prasad P. V., \& Boote, K. J. (2002). Influence of integrated use of farmyard manure and inorganic fertilizers on yield and yield components of irrigated lowland rice. Journal of Plant Nutrition, 25(10), 2081-2090.

[43] Gill, J. S., \& Walia, S. S. (2014). Influence of FYM, brown manuring and nitrogen levels on direct seeded and transplanted rice (Oryza sativa L.) A review. Research Journal of Agricultural and Environmental Sciences, 3(9), 417-426.

[44] Ramasamy, P. K., \& Suresh, S. N. (2011). Effect of vermicompost on root numbers and length of sunflower plant (Helianthus annuus L.). Journal of Pure and Applied Microbiology, 4(1), 297-302.

[45] Hatti, S. S., Londonkar, R. L., Patil, S. B., Gangawane, A. K., \& Patil, C. S. (2010). Effect of Eisenia fetida vermiwash on the growth of plants. Crop Science, 1(1), 6-10.

[46] Rekha, G. S., Valivittan, K., \& Kaleena, P. K. (2013). Studies on the influence of vermicompost and vermiwash on the growth and productivity of black gram (Vigna mungo). Advance in Biological Regulation, 7(4), 114-121.

[47] Atiyeh, R. M., Arancon, N., Edwards, C. A., \& Metzger, J. D. (2002). The influence of earthworm-processed pig manure on the growth and productivity of marigolds. Bioresource Technology, 81, 103-108.

[48] Singh, M., \& Wasnik, K. (2013). Effect of vermicompost and chemical fertilizer on growth, herb, oil yield, nutrient uptake, soil fertility, and oil quality of rosemary. Communications in Soil Science Plant Analysis, 44(18), 2691-2700.

[49] Atiyeh, R. M., Dominguez, J., Subler, S., Edwards, C. A. (2000). Changes in biochemical properties of cow manure during processing by earthworms (Eisenia andrei, Bouché) and the effects on seedling growth. Pedobiologia, 44, 709-724.

[50] Edwards, C. A., Dominguez, J., \& Arancon, N. Q. (2004). The influence of vermicomposts on plant growth and pest incidence. In: Soil Zoology for Sustainable Development in the 21st Century (Shakir, S. H., Mikhaïl, W. Z. A., Eds.), Cairo, pp. 397-420.

[51] Lazcano, C., Arnold, J., Tato, A., Zaller, J. G., \& Domínguez, J. (2009). Compost and vermicompost as nursery pot components: Effects on tomato plant growth and morphology. Span. Journal of Agricultural Research, 7, 944-951.

[52] Arancon, N. Q., Edwards, C. A., Babenko, A., Cannon, J., Galvis, P., \& Metzger, J. D. (2008). Influences of vermicomposts, produced by earthworms and microorganisms from cattle manure, food waste and paper waste, on the germination, growth and flowering of petunias in the greenhouse. Applied Soil Ecology, 39, 91-99.

[53] Arancon, N. Q., Edwards, C. A., Bierman, P., Welch, C., \& Metzger, J. D. (2004). The influence of vermicompost applications to strawberries: Part I. Effects on growth and yield. Bioresource Technology, 93, 145-153.

[54] Arancon, N. Q., Edwards, C. A., \& Atiyeh, R. (2004). Effects of vermicomposts produced from food waste on the growth and yields of greenhouse peppers. Bioresource Technology, 93, 139-144.

[55] Atiyeh, R. M., Dominguez, J., Subler, S., \& Edwards, C. A. (2000). Changes in biochemical properties of cow manure during processing by earthworms (Eisenia andrei, Bouché) and the effects on seedling growth. Pedobiologia, 44, 709-724.

[56] Singh, R., Sharma, R. R., Kumar, S., Gupta, R. K., \& Patil, R. (2008). Vermicompost substitution influences growth, physiological disorders, fruit yield and quality of strawberry (Fragaria xananassa Duch.). Bioresource Technology, 99, 8507-8511.

[57] Gutierrez-Miceli, F. A., Santiago-Borraz, J., Molina, J. A. M., Nafate, C. C., Abud-Archila, M., Llaven, M. A. O., Rincon-Rosales, R., \& Dendooven, L. (2007). Vermicompost as a soil supplement to improve growth, yield and fruit quality of tomato (Lycopersicum esculentum). Bioresource Technology, 98(15), 2781-2786.

[58] Suhane, R. K. (2007). Vermicompost. Rajendra Agriculture University, Pusa, pp. 88.

[59] Tomati, U., \& Galli, E. (1995). Earthworms, soil fertility and plant productivity. Acta Zoologica Fennica, 196, 11-14.

[60] Grapelli, A., Tomati, U., Galli, E., \& Vergari, B. (1985). Earthworm casting in plant propagation. Horticultural Science, 20, 874-876.

[61] Federico, J. S., Borraz, J.A., Molina, M., Nafate, C., Archila, C., \& Oliva, L. M. (2007). Vermicompost as a soil supplement to improve growth, yield and fruit quality of tomato (Lycopersicum esculentum). Bioresource Technology, 98(15), $2781-2786$. 
[62] Kale, R. D. \& Bano, K. (1986). In: Proceedings Nat. Semi on Organic waste Utilization. pp. 151-160.

[63] Jadhav, A. D. (1997). J. Maharashtra agriculture University, 22, 249-250.

[64] Nagarajan, S. (1997). Kisan World, 24(8), 49-50.

[65] Sarwar, G., Hussain, N., Schmeisky, H., \& Muhammad, S. (2007). Use of compost an environment friendly technology for enhancing rice-wheat production in Pakistan. Pak. Journal of Botany, 39(5), 1553-1558.

[66] Sarwar, G., N. Hussain, H. Schmeisky, S. Muhammad, M. Ibrahim, and E. Safdar. (2008). Improvement of soil physical and chemical properties with compost application in rice-wheat cropping system. Pakistan Journal of Botany, 40, $275-282$.

[67] Gopinath, K. A., Saha, S., Mina, B. L., Pande, H., Kundu, S., \& Gupta, H. S. (2008). Influence of organic amendments on growth, yield and quality of wheat and on soil properties during transition to organic production. Nutrient Cycling in Agroecosystems, 82, 51-60.

[68] Grigatti, M., Giorgonni, M., \& Ciavatta, C. (2007). Compost-based growing media: influence on growth and nutrient use of bedding plants. Bioresource Technology, 98, 3526-3534.

[69] Aslam, Z., \& Ahmad, A. (2020). Effects of vermicompost, vermi-tea and chemical fertilizer on morpho-physiological characteristics of maize (Zea mays L.) in Suleymanpasa District, Tekirdag of Turkey. Journal of Innovative Sciences, 6(1), 41-46.

[70] Lim, S. L., Wu, T. Y., Lim, P. N., \& Shak, K. P. (2015). The use of vermicompost in organic farming: overview, effects on soil and economics. Journal of the Science of Food and Agriculture, 95(6), 1143-1156.

[71] Adhikary, S. (2012). Vermicompost, the story of organic gold: A review. Agricultural Sciences, 3(7), 905-917.

[72] Hendriksen. (1997). Production of earthworm Eisenia fetida has a potential economical source of protein. Biotechnology and Bioengineering, 23, 1812-1997.

[73] Jeyabal, G., \& Kuppuswamy. (2001). Recycling of organic wastes for the production of vermicompost and its response in rice-legume cropping system and soil fertility. European Journal of Agronomy, 15(3), 153170.

[74] Rose, C. J. \& Wood, A. W. (1980). Some environmental factors affecting earthworm populations and sweet potato production in Tari basin, Papua New Guniea Highlands. Papua New Guinea. Journal of Agricultural Science, 31, 1-13.

[75] Arancon, N., Lee, S., Edwards, C., \& Atiyeh, R. (2003). Effects of humic acids derived from cattle, food and paper-waste vermicomposts on the growth of greenhouse plants. Pedobiologia, 47(5), 741-744.

[76] Postma, J., Montanari, M., \& Vanden Boogert, P. H. J. F. (2003). Microbial enrichment to enhance disease suppressive activity of compost. European Journal of Soil Biology, 39, 157-163.

[77] Perner, H., Schwarz, D., \& George, E. (2006). Effect of mycorrhizal inoculation and compost supply on growth and nutrient uptake of young leek plants growth on peat-based substrates. Horticultural Science, 41, 628-632.

[78] Lee, K. E. (1992). Some trends on opportunities in earthworm research or: Darwin's children—the future of our discipline. Soil Biology and Biochemistry, 24, 1765-1771.

[79] Casenave, C., \& Valentin. (1988). In Surface states: one of the keys to Sahelian hydrology. Proc. Sahel Forum on the state-of-the-art of hydrology and hydrogeology in the arid and semi-arid areas of Africa. (UNESCO/IWRA, Urbana, IL, USA. 61-72).

[80] Lee, K. E. (1985). Earthworms, their Ecology and Relationships with Land Use. Academic Press, Sydney, p. 411.

[81] Lee, K. E. (1992). Soil Biology and Biochemistry, 24, 1765-1771.

[82] Maheswarappa, H. P., Nanjappa, H. V., \& Hegde, M. R. (1999). Influence of organic manures on yield of arrowroot, soil physico-chemical and biological properties when grown as intercrop in coconut garden. Annals of Agricultural Sciences, 20, 318-323.

[83] Khang, B. T. (1994). Soil Fertility, 18, 193-199.

[84] Parmelee, R.W., \& Crossley, D. A. J. (1988). Earthworm production and role in the nitrogen cycle of a no-tillage agroecosystem on the Georgia piedmont. Pedobiologia, 32, 355-366.

[85] Tiwari, K. N. (1989). Fertilizer management in cropping system for increased efficiency. Fertility News, 25(3), 3-20.

[86] Hulugalle, N. R., \& Ezumah, R. G. (1991). Effects of cassava-based cropping system on physiological properties of soil and earthworm casts in a tropical Alfisol. Agriculture Ecosystems and Environment, 35, 55-63. 